Hanken, J., and P. W. Sherman. 1981. Multiple paternity in Belding's ground squirrel litters. Science, 212:351-353.

LeVEne, H. 1949. On a matching problem arising in genetics. Ann. Math. Stat., 20:91-94.

McCracken, G. F., and J. W. Bradbury. 1977. Paternity and genetic heterogeneity in the polygynous bat, Phyllostomus hastatus. Science, 198: 303-306.

- 1981. Social organization and kinship in the polygynous bat Phyllostomus hastatus. Behav. Ecol. Sociobiol., 8:11-34.

Nevo, E. 1978. Genetic variation in natural populations: pattern and theory. Theor. Pop. Biol., 13: 121-177.

Porter, F. L. 1978. Roosting patterns and social behavior in captive Carollia perspicillata. J. Mamm., 59:627-630.

1979a. Social behavior in the leaf-nosed bat, Carollia perspicillata I: social organization. Z. Tierpsychol., 49:406-417.

1979b. Social behavior in the leaf-nosed bat, Carollia perspicillata II: social communication. Z. Tierpsychol., 50: 1-8.

Rasweiler, J. J., and H. DE Bonilla. 1972. Laboratory maintenance methods for some nectar- ivorous and frugivorous phyllostomatid bats. Lab. Anim. Sci., 22: 658-663.

Schwartz, O. A., ANd K. B. Armitage. 1980. Genetic variation in social mammals: the marmot model. Science, 207:665-667.

SElander, R. K. 1976. Genetic variation in natural populations. Pp. 21-45, in Molecular evolution ( $\mathrm{F}$. J. Ayala, ed.). Sinauer Associates, Sunderland, Massachusetts, $277 \mathrm{pp}$.

Selander, R. K., M. H. Smith, S. V. Yang, W. E. Johnson, AND J. B. Gentry. 1971. Biochemical polymorphism and systematics in the genus Peromyscus. I: variation in the old-field mouse. Univ. Texas Publ., Stud. Genet., 6(7103):49-90.

Straney, D. O., M. H. Smith, I. F. Greenbaum, and R. J. BAKER. 1979. Biochemical genetics. Pp. 157176 , in Biology of bats of the New World family Phyllostomatidae. Part III (R. J. Baker, J. Knox Jones, Jr., and D. C. Carter, eds.). Texas Tech Press, Lubbock Texas, 441 pp.

Wilson, D. E. 1979. Reproductive patterns. Pp. $317-378$, in Biology of bats of the New World family Phyllostomatidae. Part III (R. J. Baker, J. Knox Jones, Jr., and D. C. Carter, eds.). Texas Tech Univ. Press, Lubbock, Texas, 441 pp.

Fran Lang Porter and Gary F. McCracken, Department of Physiology and Biophysics, Washington University School of Medicine, St. Louis, MO 63110 and Department of Zoology, University of Tennessee, Knoxville, TN 37996-0810 (present address of Porter: Department of Pediatrics, St. Louis Children's Hospital, 500 S. Kings Highway, P.O. Box 14871, St. Louis, MO 63178). Submitted 3 May 1982. Accepted 10 October 1982.

\title{
REPRODUCTION IN THE ARCTIC SHREW, SOREX ARCTICUS
}

The arctic shrew, Sorex arcticus, is found in northern boreal environments from the Northwest Territories southeast to the north-central United States and eastern Canada. We consider S. arcticus specifically distinct from the northern populations (Sorex tundrensis) in Alaska and northwestern Canada (see Youngman, 1975; Nagorsen and Jones, 1981). Arctic shrews are found in a variety of habitats, but populations generally are highest in nonforested areas, either marshes or grassy clearings within forests. The ecology and life history of arctic shrews have been reported previously (Quimby, 1943; Clough, 1960, 1963; Buckner, 1964, 1966; Whitaker and Pascal, 1971); however, data on reproduction are limited. The purpose of this report is to present data on reproduction of Sorex arcticus.

The study area was located in the Carlos Avery Game Management Area, Anoka Co., approximately 45 $\mathrm{km} \mathrm{N}$ of Minneapolis, Minnesota $\left(45^{\circ} 15^{\prime} \mathrm{N}, 93^{\circ} 07^{\prime} \mathrm{W}\right)$. The area is characterized by generally flat topography and poorly drained soils located on the Anoka Sand Plain, a region of glacial outwash sand. Trapping was conducted from 1973 to 1977 , in a wet, grass-sedge meadow. The vegetation was dominated by reed canary grass (Phalaris arundinacea). Patches of reed grass (Calamagrostis canadensis) and sedges (Carex spp.) grew with or replaced the dominant species. Litter provided dense cover throughout the year. Microtus pennsylvanicus was the most common small mammal taken throughout the study. For details on the vegetation, climate, soils, and other mammals of the management area, see Baird (1980) and Rand (1953).

Bait (oatmeal and peanut butter or oatmeal and anise oil), trapping dates (every three weeks from late June to September, with occasional trapping during other months), and trap settings were designed for studying dispersal in the population of M. pennsylvanicus (Baird and Birney, 1982). However, during this study over 200 Sorex arcticus were captured and removed. Most S. arcticus were captured in Sherman live traps, but other live traps and snap trapping also resulted in occasional captures. Because the study design was not developed for describing dynamics of the shrew population, our data cannot be used to assess 
TABLE 1.-Number of female and male Sorex arcticus examined (N) and number reproductively active by month. Data from years 1973-1977 are pooled.

\begin{tabular}{|c|c|c|c|c|}
\hline & \multicolumn{2}{|c|}{ Females } & \multicolumn{2}{|c|}{ Males } \\
\hline & $\bar{N}$ & Reproductive & $\mathbf{N}$ & Reproductive \\
\hline $\operatorname{Mar}^{1}$ & 0 & - & 0 & - \\
\hline Apr & 1 & 1 & 1 & 1 \\
\hline May & 12 & 12 & 6 & 6 \\
\hline Jun & 6 & 6 & 7 & 2 \\
\hline Jul & 38 & 14 & 28 & 5 \\
\hline Aug & 23 & 5 & 25 & 1 \\
\hline Sep & 12 & 2 & 13 & 0 \\
\hline Oct & 20 & 0 & 15 & 0 \\
\hline Nov & 0 & - & 0 & - \\
\hline Dec & 1 & 0 & 0 & - \\
\hline Total & 113 & 40 & 95 & $15^{2}$ \\
\hline
\end{tabular}

${ }^{1}$ No trapping was done in January or February.

${ }_{2}$ Of the 15 reproductively active males, testes size ranged from $6 \times 3$ to $7 \times 5 \mathrm{~mm}$. Nonreproductive males had testes of $1 \times 1$ to $2 \times 1$ mm.

population parameters such as density or reproductive rate, and may include trap bias (e.g., larger shrews may have been more likely to trip the trap mechanisms).

Standard external measurements (total length, length of tail vertebrae, length of hind foot, and height of ear from notch) and weight were recorded for all arctic shrews removed from the study area. Most (187 of 208) shrews were classified as subadult or adult based on pelage (Clough, 1963). Clough (1963) reported that young-of-the-year molted from bicolor to adult tricolor pelage in their first autumn and then maintained adult pelage throughout their lives. Our data were consistent with this pattern. Testes length and width were recorded for males. Those with testis lengths of at least $6 \mathrm{~mm}$ were considered reproductively active. For females the following reproductive data were recorded: 1) mammae-small, large, or lactating; 2) embryos-number left and right and crown-to-rump length in $\mathrm{mm}$; 3) uterine scars-number left and right; 4) corpora lutea-number left and right; 5) condition of uterus-short and $<1 \mathrm{~mm}$ in width, or long and $>1 \mathrm{~mm}$ in width. Females with embryos or corpora lutea and those lactating were considered reproductively active. Reference specimens of arctic shrews from this locality are deposited in the Bell Museum of Natural History, University of Minnesota, Minneapolis, and the Field Museum of Natural History, Chicago.

Our earliest record of breeding was found in two shrews captured during the first week of April (Table 1). One, an adult male, was in reproductive condition as indicated by a testis size of $6 \times 3 \mathrm{~mm}$. The other, an adult female, was lactating. Adults of both sexes continued to be captured through the months of May, June, and July. During these months adults usually were reproductively active when examined (30 of the 31 adult females and 11 of the 13 adult males). No adult males were captured in August. The single adult male captured in September was not reproductively active and may have been a young-of-the-year that had undergone the fall molt to adult pelage. Adult females continued to be captured in August and September. Of five adult females captured in August, all were reproductively active. Of four adult females captured in September, two were lactating and the other two were not reproductively active. No reproductive activity was recorded for October.

The first young-of-the-year were recorded in June. Subadults rarely showed reproductive activity during the summer months. Only one of the 47 subadult males captured in June-August had enlarged testes $(6 \times$ $5 \mathrm{~mm}$ ). Of the 39 subadult females examined, two were reproductively active: one was pregnant and one was lactating.

These data suggest a pattern of reproduction similar to that reported for a population in southern Wisconsin (Clough, 1963). There, individuals were in breeding condition from February through August, and most young-of-the-year did not breed. The only other extensive study of reproduction in S. arcticus was conducted in southeastern Manitoba (Buckner, 1966). That population also bred from late winter through summer, but young of the first litter of the year usually bred during the summer.

Females with embryos or corpora lutea from which litter size can be estimated are listed (Table 2). Ten females exhibited visible implanted embryos. Their embryo counts ranged from 5 to 9 with an average of 7.7 ( $\mathrm{SE}=0.42$ ). Counts of corpora lutea ranged from 5 to 9 with an average of $7.3(\mathrm{SE}=0.36)$ for the 15 nonpregnant females with corpora. By combining embryo and corpora lutea data, the estimate of litter size for these 25 females is 7.5 .

Literature reports of litter size in S. arcticus consist of data on 25 females with embryos. Buckner (1966) 
TABLE 2.-Reproductive data for female Sorex arcticus with embryos or corpora lutea. ${ }^{1}$ Number of embryos and corpora on the left $(L)$ and right $(R)$ are indicated. Crown-rump length (CR) of embryos is given in $\mathrm{mm}$.

\begin{tabular}{|c|c|c|c|c|c|c|c|c|}
\hline & & & \multicolumn{3}{|c|}{ Embryos } & \multicolumn{2}{|c|}{ Corpora } & \multirow[b]{2}{*}{ Lactation } \\
\hline \multicolumn{2}{|c|}{ Date } & \multirow{2}{*}{$\frac{\text { Pelage }}{\text { adult }}$} & \multirow{2}{*}{$\frac{\mathrm{L}}{0}$} & \multirow{2}{*}{$\begin{array}{l}\mathbf{R} \\
0\end{array}$} & \multirow[t]{2}{*}{ (CR) } & \multirow{2}{*}{$\frac{\mathrm{L}}{1}$} & \multirow{2}{*}{$\frac{\mathrm{R}}{8}$} & \\
\hline $02 \mathrm{Apr}$ & 1976 & & & & & & & lactating \\
\hline 15 May & 1974 & adult & 0 & 0 & & 6 & 2 & lactating \\
\hline 16 May & 1974 & adult & 0 & 0 & & 0 & 6 & lactating \\
\hline 16 May & 1974 & adult & 0 & 0 & & 5 & 1 & not lactating \\
\hline 16 May & 1974 & adult & 0 & 0 & & 5 & 2 & lactating \\
\hline 16 May & 1974 & adult & 0 & 0 & & 4 & 5 & lactating \\
\hline 16 May & 1974 & adult & 0 & 0 & & 3 & 3 & lactating \\
\hline 17 May & 1974 & adult & 0 & 0 & & 6 & 3 & lactating \\
\hline 17 May & 1974 & adult & 4 & 4 & $(02)$ & 5 & 3 & not lactating \\
\hline 20 May & 1974 & adult & 0 & 0 & & 5 & 3 & lactating \\
\hline 22 May & 1974 & adult & 0 & 0 & & 6 & 3 & lactating \\
\hline 22 May & 1974 & adult & 3 & 4 & (11) & 0 & 0 & not lactating \\
\hline 23 May & 1974 & adult & 4 & 4 & (11) & no & & not lactating \\
\hline 09 Jun & 1977 & adult & 0 & 0 & & 4 & 4 & lactating \\
\hline 25 Jun & 1974 & adult & 5 & 3 & (17) & 0 & 0 & not lactating \\
\hline 26 Jun & 1974 & adult & 0 & 0 & & 1 & 5 & lactating \\
\hline $02 \mathrm{Jul}$ & 1974 & adult & 4 & 5 & (12) & 0 & 0 & not lactating \\
\hline $03 \mathrm{Jul}$ & 1974 & adult & 0 & 0 & & 2 & 6 & lactating \\
\hline $15 \mathrm{Jul}$ & 1974 & adult & 0 & 0 & & 2 & 3 & lactating \\
\hline $15 \mathrm{Jul}$ & 1974 & adult & 0 & 0 & & 4 & 2 & lactating \\
\hline $18 \mathrm{Jul}$ & 1974 & adult & 4 & 5 & (11) & no & & not lactating \\
\hline $23 \mathrm{Jul}$ & 1974 & adult & 2 & 3 & (12) & 0 & 0 & not lactating \\
\hline $24 \mathrm{Jul}$ & 1975 & no record & 3 & 5 & (11) & no & & not lactating \\
\hline $25 \mathrm{Jul}$ & 1975 & subadult & 5 & 4 & (03) & $\begin{array}{r}\text { nu } \\
\text { unc }\end{array}$ & & not lactating \\
\hline 21 Aug & 1974 & adult & 3 & 3 & (13) & no & & not lactating \\
\hline
\end{tabular}

${ }^{1}$ Three lactating females with no embryos and an uncertain number of corpora lutea are not included in the table.

reported a mean litter size of 6 for 12 females from a population in Manitoba. Clough (1963) reported embryo counts of 4, 5, 7, and 8 for females from a population in Wisconsin as well as one female with 6 embryos from another Wisconsin population. Jackson (1961) reported counts of 6, 6, 8, and 9 for females from still another Wisconsin population. Bailey (1929) reported counts of 9 and 6 for females from Minnesota. Smith (1940) reported two pregnant females from Nova Scotia with 5 and 7 embryos.

An additional four specimens not previously reported have been found. Three females in the Bell Museum collection, (specimens 3882 and 14192 from Minnesota and 9783 from North Dakota) have embryo counts of 7, 3, and 9, respectively. A female collected in Minnesota had 6 embryos (Kirkland, pers. comm.). The average litter size for the combined 29 females is 6.3 ( $\mathrm{SE}=0.25)$, significantly fewer $\left(t_{37}=2.84 ; P<0.01\right)$ than the 7.7 reported here for 10 pregnant females or the $7.3\left(t_{42}=2.36 ; P<0.05\right)$ reported here for the 15 females with corpora lutea but no embryos. The potential bias in our trapping techniques for larger females may account for some of this difference.

Only two females exhibited both embryos and corpora lutea; one was an adult female with embryos 2 $\mathrm{mm}$ in length, and the other a subadult female with embryos $3 \mathrm{~mm}$ in length. Thus, the corpora lutea must usually degenerate very early after development begins. Uterine scars were rarely observed, even in lactating females, indicating that scars cannot be used as a reliable measure of previous pregnancy. Fifteen females exhibited corpora lutea but no embryos or scars, suggesting the association of corpora with unimplanted embryos. This is further substantiated by the following seasonal pattern in lactating females. All but one of the 14 lactating females captured in April, May, and June had corpora lutea (this includes 11 lactating females in Table 2 and two females with an undetermined number of corpora lutea not shown in Table 2). Four of the eight lactating females captured in July had corpora lutea (this includes three lactating females in Table 2 and one female with an undetermined number of corpora lutea not listed in Table 2). None of the five lactating females captured in August or September had corpora lutea. If corpora lutea in lactating females were associated with the previous pregnancy, no seasonal pattern would be expected. If corpora 
lutea were associated with a future litter, this seasonal pattern would be expected because late in the breeding season lactating females would not be expected to have an immediately subsequent litter.

The pattern of occurrence of corpora lutea among females in this study raises questions about the reproductive biology of S. arcticus. Many lactating females exhibited corpora lutea, probably associated with unimplanted embryos of a subsequent litter. Yet, no female we examined showed visible embryos while lactating. This suggests implantation may be delayed until lactation has ceased. Delayed implantation during lactation has been reported for Sorex araneus (Brambell, 1935) and Neomys fodiens (Asdell, 1964).

An alternative explanation also must be considered. What we have identified to be corpora lutea under a binocular scope may have been mature follicles. If so, ovulation rather than implantation may be delayed until lactation ceases. Blarina brevicauda apparently exhibits this alternative pattern. Estrus occurs after the previous litter is weaned, some 20 or more days after parturition, and ovulation is induced by copulation (Pearson, 1944).

These alternative hypotheses can be tested by histological analysis of the ovarian structures that look like corpora lutea under low magnification. Behavioral data on timing of estrus and breeding in relation to lactation also would provide relevant evidence.

The staff at Carlos Avery Game Farm provided assistance throughout the trapping periods. We thank E. C. Birney, G. N. Cameron, B. L. Clauson, L. R. Heaney, B. D. Patterson, and a very conscientious anonymous reviewer for their constructive comments on the manuscript.

\section{Literature Cited}

AsDELl, S. A. 1964. Patterns of mammalian reproduction. Second ed. Cornell Univ. Press, Ithaca, $670 \mathrm{pp}$.

BAILEY, B. 1929. Mammals of Sherburne County, Minnesota. J. Mamm., 10:153-164.

BaIRD, D. D. 1980 . Dispersal in meadow voles, $M i$ crotus pennsylvanicus. Unpubl. Ph.D. dissert., Univ. Minnesota, Minneapolis, 111 pp.

BaIRD, D. D., AND E. C. Birney. 1982. Characteristics of dispersing meadow voles Microtus pennsylvanicus. Amer. Midland Nat., 107:262-283.

Brambell, F. W. R. 1935. Reproduction in the common shrew (Sorex araneus Linnaeus). Trans. Royal Soc. London, Ser. B, 225:1-62.

BUCKNER, C. H. 1964. Metabolism, food capacity, and feeding behavior in four species of shrews. Canadian J. Zool., 42:259-279.

- 1966. Populations and ecological relationships of shrews in tamarack bogs of southeastern Manitoba. J. Mamm., 47:181-194.

Clough, G. C. 1960. Arctic shrew in southern Wisconsin. J. Mamm., 41:263.

-1963. Biology of the arctic shrew, Sorex arcticus. Amer. Midland Nat., 69:69-81.
JACKSON, H. H. T. 1961. Mammals of Wisconsin. Univ. Wisconsin Press, Madison, 504 pp.

Nagorsen, D. W., and D. M. Jones. 1981. First records of the tundra shrew (Sorex tundrensis) in British Columbia. Canadian Field-Nat., 95:93-94.

Pearson, O. P. 1944. Reproduction in the shrew (Blarina brevicauda Say). Amer. J. Anat., 75:3993.

Quimby, D. 1943. Notes on the long-tailed shrews in Minnesota. J. Mamm., 24:261-262.

Rand, P. J. 1953. The plant communities and history of the Carlos Avery Game Refuge, Anoka County, Minnesota. Unpubl. M.S. thesis, Univ. Minnesota, Minneapolis, $168 \mathrm{pp}$.

Sмith, R. W. 1940. The land mammals of Nova Scotia. Amer. Midland Nat., 24:213-241.

Whitaker, J. O., JR., and D. D. Pascal, Jr. 1971. External parasites of arctic shrews (Sorex arcticus) taken in Minnesota. J. Mamm., 52:202.

Youngman, P. M. 1975. Mammals of the Yukon Territory. Publ. Zool., Nat. Mus. Nat. Sci., Ottawa, 10:1-192.

Donna Day Baird, Robert M. Timm, and Gerda E. Nordquist, Bell Museum of Natural History, University of Minnesota, Minneapolis, MN 55455. (Present addresses of Baird and Timm: Division of Mammals, Field Museum of Natural History, Chicago, IL 60605-2496). Submitted 22 February 1982. Accepted 18 August 1982. 